\title{
Draft genome sequence of marine-derived Streptomyces sp. TP-A0598, a producer of anti-MRSA antibiotic lydicamycins
}

\author{
Hisayuki Komaki ${ }^{*}$, Natsuko Ichikawa ${ }^{2}$, Akira Hosoyama ${ }^{2}$, Nobuyuki Fujita ${ }^{2}$ and Yasuhiro Igarashi ${ }^{3}$
}

\begin{abstract}
Streptomyces sp. TP-A0598, isolated from seawater, produces lydicamycin, structurally unique type I polyketide bearing two nitrogen-containing five-membered rings, and four congeners TPU-0037- $A,-B,-C$, and $-D$. We herein report the $8 \mathrm{Mb}$ draft genome sequence of this strain, together with classification and features of the organism and generation, annotation and analysis of the genome sequence. The genome encodes 7,240 putative ORFs, of which 4,450 ORFs were assigned with COG categories. Also, 66 tRNA genes and one rRNA operon were identified. The genome contains eight gene clusters involved in the production of polyketides and nonribosomal peptides. Among them, a PKS/NRPS gene cluster was assigned to be responsible for lydicamycin biosynthesis and a plausible biosynthetic pathway was proposed on the basis of gene function prediction. This genome sequence data will facilitate to probe the potential of secondary metabolism in marine-derived Streptomyces.
\end{abstract}

Keywords: Lydicamycin, TPU-0037, Biosynthetic gene, Polyketide synthase, Streptomyces

\section{Introduction}

Members of the genus Streptomyces, Gram-positive filamentous actinomycetes, are an attractive source for bioactive secondary metabolites. Terrestrial surface soil is the most common habitat for Streptomyces but a recent survey has disclosed its ubiquitous distribution in marine environments. Marine Streptomyces are currently attracting much attention as an untouched resource of novel bioactive compounds useful for drug development [1-3]. In our screening for new anti-MRSA antibiotics, Streptomyces sp. TP-A0598 collected from deep sea water was found to produce lydicamycin and its four new congeners of polyketide origin (Fig. 1) [4]. Lydicamyicn is characterized by the unprecedented pyrrolidine ring modified by an aminoiminomethyl group to which a polyketide-derived carbon chain with multiple hydroxyl and olefinic functionalities is linked and to the other end of the chain is linked an octalin modified by a tetramic acid. Despite this unique

\footnotetext{
* Correspondence: komaki-hisayuki@nite.go.jp

${ }^{1}$ Biological Resource Center, National Institute of Technology and Evaluation (NBRC), Chiba, Japan

Full list of author information is available at the end of the article
}

structural feature, biosynthetic genes of lydicamycin have not been reported to date. In this study, we conducted whole genome shotgun sequencing of the strain TP-A0598 to identify the PKS gene cluster for lydicamycin. We herein present the draft genome sequence of Streptomyces sp. TP-A0598, together with the description of genome properties and annotation for secondary metabolite genes. The putative lydicamycin biosynthetic gene cluster and a plausible biosynthetic pathway are also reported.

\section{Organism information}

\section{Classification and features}

In the course of screening for new bioactive molecules produced by marine microorganisms, Streptomyces sp. TP-A0598 was isolated from a seawater sample collected in 2,600 meters off the shore and 321 meters in depth at Namerikawa, Toyama, Japan by a membrane filter method and found to produce lydicamycin and its novel congeners. This strain grew well on Bennett's, ISP 3, ISP 4, ISP 5 and Yeast starch agars. On ISP 5, ISP 6 and ISP 


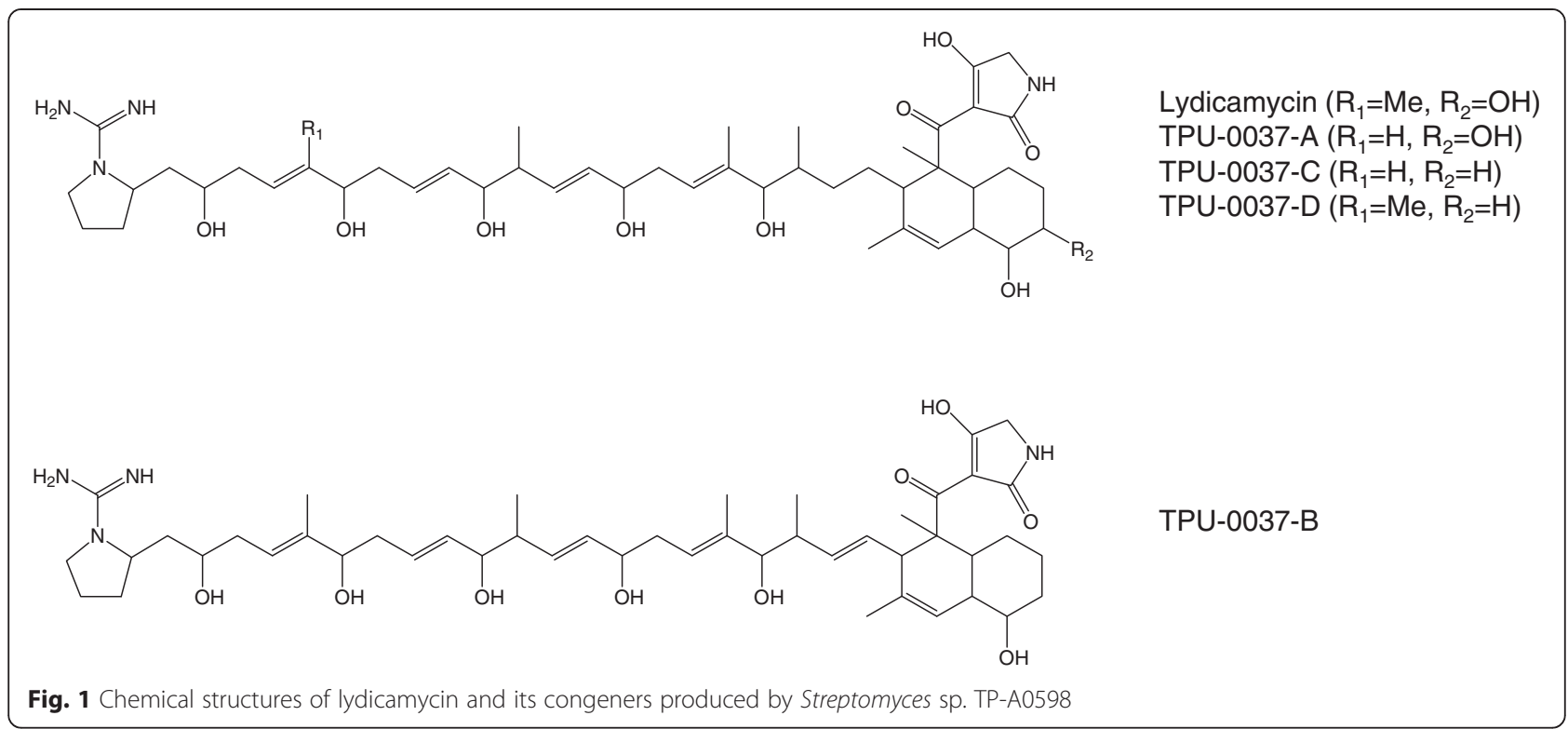

7 agars, the growth was poor. The color of aerial mycelia was grayish olive and that of the reverse side was pale yellow on ISP 3 agar. Diffusible pigments were not formed on any agar media that we examined. Strain TPA0598 formed spiral spore chains and the spores were cylindrical, $0.5 \times 0.9 \mu \mathrm{m}$ in size, having a warty surface [4]. A scanning electron micrograph of this strain is shown in Fig. 2. Growth occurred at $15-37{ }^{\circ} \mathrm{C}$ (optimum $30{ }^{\circ} \mathrm{C}$ ) and pH 5-9 (optimum pH 7). Strain TP-A0598 exhibited growth with $0-7 \%(\mathrm{w} / \mathrm{v}) \mathrm{NaCl}$ (optimum $0 \%$ $\mathrm{NaCl}$ ). Strain TP-A0598 utilized D-glucose, sucrose, inositol, L-rhamnose, D-mannitol, D-raffinose, D-fructose,
L-arabinose, and D-xylose for growth (Table 1) [4]. This strain was deposited in the NBRC culture collection with the registration number of NBRC 110027. The genes encoding $16 \mathrm{~S}$ rRNA were amplified by PCR using two universal primers, $9 \mathrm{~F}$ and 1541R. After purification of the PCR product by AMPure (Beckman Coulter), the sequencing was carried out according to a established methods [5]. Homology search of the sequence by EzTaxon-e [6] indicated the highest similarity (99.93 \%, 1465/1466) to Streptomyces angustmyceticus NBRC $3934^{\mathrm{T}}$ (AB184817) [7] as the closest type strain. A phylogenetic tree was reconstructed on the basis of the 16S rRNA gene

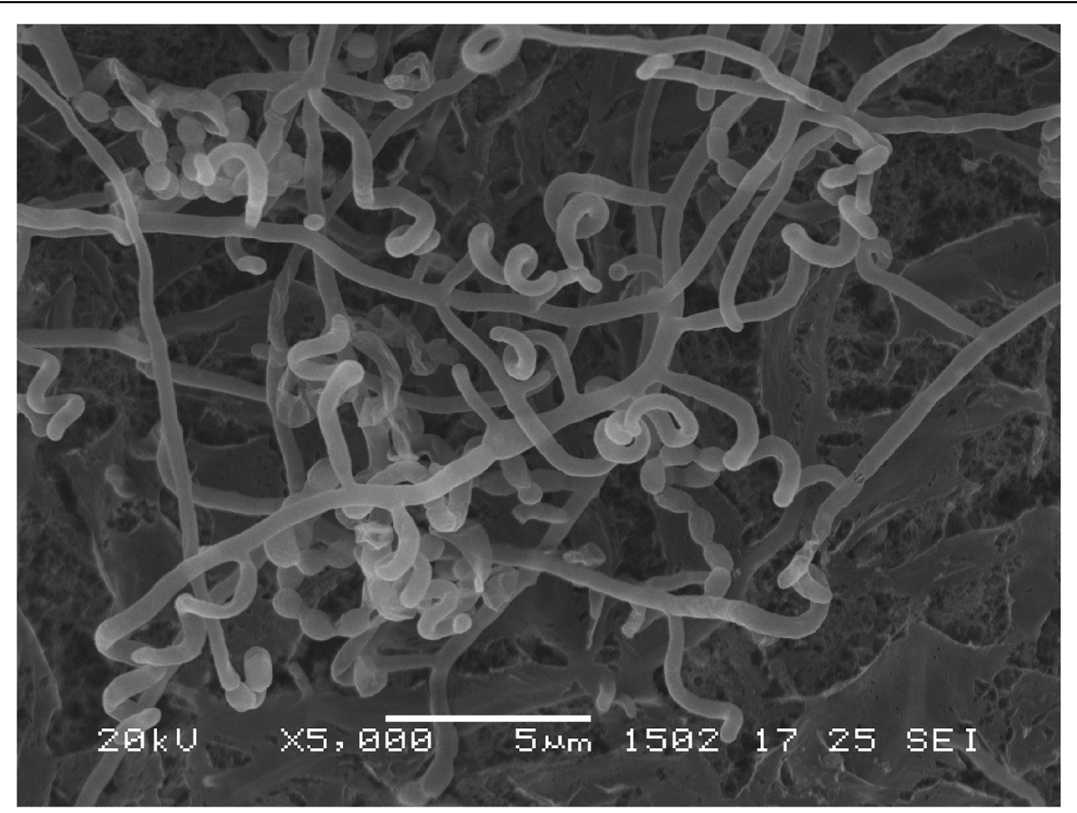

Fig. 2 Scanning electron micrograph of Streptomyces sp. TP-A0598 grown on ten-fold diluted ISP 2 medium agar for 11 days at $28^{\circ} \mathrm{C}$. Bar, $5 \mu \mathrm{m}$ 
sequence together with phylogenetic neighbors that showed over $98.5 \%$ similarity (Fig. 3) using ClustalX2 [8] and NJplot [9]. The phylogenetic analysis confirmed that the strain TP-A0598 belongs to the genus Streptomyces.

\section{Chemotaxonomic data}

The whole-cell hydrolysates of strain TP-A0598 contained L,L-diaminopimelic acid, glycine, ribose and madurose. The cellular fatty acids consisted of $21 \%$ 14-methylpentadecanoic acid (iso $\mathrm{C}_{16}$ ), 9 \% 13-methyltetradecanoic acid (iso $\mathrm{C}_{15: 0}$ ), $8 \%$ 12-methyltetradecanoic acid (anteiso $\mathrm{C}_{15: 0}$ ) and other minor fatty acids [4].

\section{Genome sequencing information Genome project history}

In collaboration between Toyama Prefectural University and NBRC, the organism was selected for genome sequencing to elucidate the lydicamycin biosynthetic gene cluster. We successfully accomplished the genome project of Streptomyces sp. TP-A0598 as reported in this paper. The draft genome sequence data have been deposited in the INSDC database under the accession number BBNO01000001-BBNO01000020. The project information and its association with MIGS version 2.0 compliance are summarized in Table 2 [10].

\section{Growth conditions and genomic DNA preparation}

Streptomyces sp. TP-A0598 monoisolate was grown on polycarbonate membrane filter (Advantec) on double diluted ISP 2 agar medium $(0.2 \%$ yeast extract, $0.5 \%$ malt extract, $0.2 \%$ glucose, $2 \%$ agar, pH 7.3) at $28{ }^{\circ} \mathrm{C}$. High quality genomic DNA for sequencing was isolated from the mycelia with an EZ1 DNA Tissue Kit and a Bio Robot EZ1 (Qiagen) according to the protocol for extraction of nucleic acid from Gram-positive bacteria. The size, purity, and double-strand DNA concentration of the genomic DNA were measured by pulsed-field gel electrophoresis, ratio of absorbance values at $260 \mathrm{~nm}$ and $280 \mathrm{~nm}$, and Quant-iT PicoGreen dsDNA Assay Kit (Life Technologies) to assess the quality.

\section{Genome sequencing and assembly}

Shotgun and pair-end libraries were prepared and sequenced using 454 pyrosequencing technology and HiSeq1000 (Illumina) pair-end technology, respectively (Table 2). The $70 \mathrm{Mb}$ shotgun sequences and $702 \mathrm{Mb}$ pair-end sequences were assembled into 20 scaffolds larger than 500 bp using Newbler v2.6, and subsequently finished using GenoFinisher [11].

\section{Genome annotation}

Coding sequences were predicted by Prodigal [12] and tRNA-scanSE [13]. The gene functions were annotated
Table 1 Classification and general features of Streptomyces sp. TP-A0598

\begin{tabular}{|c|c|c|c|}
\hline MIGS ID & Property & Term & $\begin{array}{l}\text { Evidence } \\
\text { code }^{a}\end{array}$ \\
\hline & Classification & Domain Bacteria & TAS [16] \\
\hline & & Phylum Actinobacteria & TAS [17] \\
\hline & & Class Actinobacteria & TAS [18] \\
\hline & & Order Actinomycetales & TAS [18-21] \\
\hline & & Suborder Streptomycineae & $\operatorname{TAS}[18,19]$ \\
\hline & & Family Streptomycetaceae & $\begin{array}{l}\text { TAS } \\
{[18-20,22,23]}\end{array}$ \\
\hline & & Genus Streptomyces & $\begin{array}{l}\text { TAS } \\
{[20,23-25]}\end{array}$ \\
\hline & & Species Streptomyces sp. & TAS [4] \\
\hline & & Strain TP-A0598 & TAS [4] \\
\hline & Gram stain & Not tested, likely positive & NAS \\
\hline & Cell shape & Branched mycelia & TAS [4] \\
\hline & Motility & Not reported & \\
\hline & Sporulation & Sporulating & TAS [4] \\
\hline & $\begin{array}{l}\text { Temperature } \\
\text { range }\end{array}$ & $\begin{array}{l}\text { Grows from } 15^{\circ} \mathrm{C} \\
\text { to } 37^{\circ} \mathrm{C}\end{array}$ & IDA \\
\hline & $\begin{array}{l}\text { Optimum } \\
\text { temperature }\end{array}$ & $30^{\circ} \mathrm{C}$ & IDA \\
\hline & $\begin{array}{l}\text { pH range; } \\
\text { Optimum }\end{array}$ & $5-9 ; 7$ & IDA \\
\hline & $\begin{array}{l}\text { Carbon } \\
\text { source }\end{array}$ & $\begin{array}{l}\text { D-glucose, sucrose, inositol, } \\
\text { L-rhamnose, D-mannitol, } \\
\text { D-raffinose, D-fructose, } \\
\text { L-arabinose, D-xylose }\end{array}$ & TAS [4] \\
\hline MIGS-6 & Habitat & Marine & TAS [4] \\
\hline MIGS-6.3 & Salinity & Grows from $0 \%$ to $7 \% \mathrm{NaCl}$ & IDA \\
\hline MIGS-22 & $\begin{array}{l}\text { Oxygen } \\
\text { requirement }\end{array}$ & Aerobic & TAS [4] \\
\hline MIGS-15 & $\begin{array}{l}\text { Biotic } \\
\text { relationship }\end{array}$ & Free-living & TAS [4] \\
\hline MIGS-14 & Pathogenicity & Not reported & \\
\hline MIGS-4 & $\begin{array}{l}\text { Geographic } \\
\text { location }\end{array}$ & $\begin{array}{l}2,600 \text { meters off the } \\
\text { shore at Namerikawa, } \\
\text { Toyama, Japan }\end{array}$ & TAS [4] \\
\hline MIGS-5 & $\begin{array}{l}\text { Sample } \\
\text { collection }\end{array}$ & Not reported & \\
\hline MIGS-4.1 & Latitude & Not reported & \\
\hline MIGS-4.2 & Longitude & Not reported & \\
\hline MIGS-4.4 & Attitude & $-321 \mathrm{~m}$ & TAS [4] \\
\hline
\end{tabular}

avidence codes - IDA: Inferred from Direct Assay; TAS: Traceable Author Statement (i.e., a direct report exists in the literature); NAS: Non-traceable Author Statement (i.e., not directly observed for the living, isolated sample, but based on a generally accepted property for the species, or anecdotal evidence). These evidence codes are the Gene Ontology project [26]

using an in-house genome annotation pipeline and domains related to PKS and NRPS were searched for using the SMART and PFAM domain databases. PKS and NRPS gene clusters and their domain organizations were 


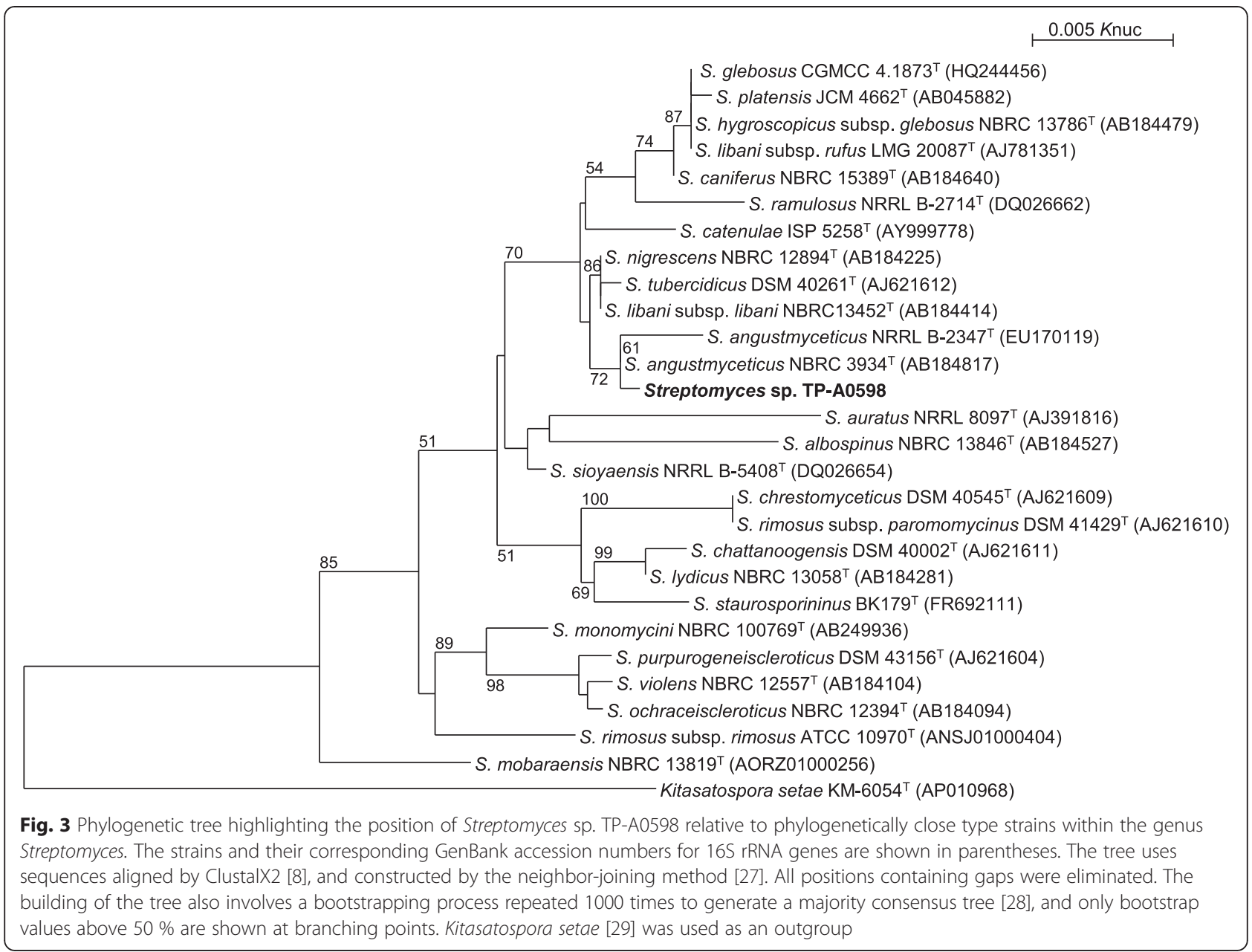

Table 2 Project information

\begin{tabular}{lll}
\hline MIGS ID & Property & Term \\
\hline MIGS 31 & Finishing quality & Improved-high-quality draft \\
MIGS-28 & Libraries used & $\begin{array}{l}454 \text { shotgun library, Illumina } \\
\text { pair-end library }\end{array}$ \\
MIGS 29 & Sequencing platforms & 454 GS FLX+, Illumina HiSeq1000 \\
MIGS 31.2 & Fold coverage & $8.4 \times$, 93 ×, respectively \\
MIGS 30 & Assemblers & Newbler v2.6 \\
MIGS 32 & Gene calling method & Progidal v2.6 \\
& Locus Tag & TPA0598 \\
& GenBank ID & BBNO00000000 \\
& GenBank Date of Release & January 6, 2015 \\
& GOLD ID & Not registered \\
& BIOPROJECT & PRJDB3150 \\
SIGS 13 & Source Material Identifier & NBRC 110027 \\
& Project relevance & Industrial \\
\hline
\end{tabular}

analyzed manually. Similarity search in the NCBI nr databases was also used for functional prediction of genes in the lydicamycin biosynthetic gene cluster.

\section{Genome properties}

The total size of the genome is $8,319,549 \mathrm{bp}$ and the GC content is $71.0 \%$ (Table 3), similar to other genome-sequenced Streptomyces members. Of the total 7,344 genes, 7,240 are protein-coding genes and 75 are RNA genes. The classification of genes into COGs functional categories is shown in Table 4. As for the secondary metabolism, Streptomyces sp. TP-A0598 has two type I PKS, two type II PKS, two NRPS, and two hybrid PKS/NRPS gene clusters, suggesting the high capacity of production of polyketides and nonribosomal peptides.

\section{Insights from the genome sequence}

The chemical structure of lydicamycin (Fig. 1) suggests that its carbon skeleton is assembled from eleven malonyl-CoA and six methylmalonyl-CoA precursors by type I PKS pathway. In addition, this pathway should be 
Table 3 Genome statistics

\begin{tabular}{lrc}
\hline Attribute & \multicolumn{1}{l}{ Value } & \% of Total \\
\hline Genome size (bp) & $8,319,549$ & 100.0 \\
DNA coding (bp) & $7,149,098$ & 85.9 \\
DNA G + C (bp) & $5,915,420$ & 71.0 \\
DNA scaffolds & 20 & 100.0 \\
Total genes & 7,344 & 100.0 \\
Protein-coding genes & 7,240 & 98.6 \\
RNA genes & 75 & 1.0 \\
Pseudo genes & 29 & 0.4 \\
Genes in internal clusters & 761 & 10.4 \\
Genes with functional prediction & 3,207 & 43.7 \\
Genes assigned to COGs & 4,450 & 60.6 \\
Genes with Pfam domains & 4,543 & 61.9 \\
Genes with signal peptides & 653 & 8.9 \\
Genes with transmembrane helices & 1,770 & 24.1 \\
CRISPR repeats & 5 & - \\
\hline
\end{tabular}

combined with NRPS pathway since lydicamycin bears a tetramic acid moiety derived from the condensation of an amino acid to the polyketide chain. We therefore searched for a type I PKS gene cluster consisting of seventeen PKS modules and an NRPS module. A hybrid PKS/NRPS gene cluster in scaffold03 (Table 5, Fig. 4) consists of seventeen PKS modules and one NRPS module (Fig. 5b). According to the assembly line rule [14], the predicted structure of the polyketide arising from this PKS/NRPS hybrid gene cluster was in good accordance with the actual structure of lydicamycin (Fig. 5b). As a starter unit for the polyketide assembly, 4-guanidinobutyryl CoA could be proposed on the basis of annotation of TPA0598_03_00880, TPA0598_03_00650 and TPA0598_03_00700. These genes were predicted to encode amine oxidase, acyl-CoA ligase, and transacylase by comparing the corresponding genes present in the ECO-02301 biosynthetic gene cluster. In the biosynthesis of ECO-02301, 4-aminobutyryl-CoA is supplied from Larginine by a sequential action of amine oxidase, acyl-CoA ligase, and amidinohydrolase and is transferred to ACP by transacylase (Fig. 5a) [15]. In the lydicamycin cluster,

Table 4 Number of genes associated with general COG functional categories

\begin{tabular}{|c|c|c|c|}
\hline Code & Value & $\%$ age & Description \\
\hline J & 196 & 2.70 & Translation \\
\hline A & 2 & 0.03 & RNA processing and modification \\
\hline K & 519 & 7.17 & Transcription \\
\hline L & 155 & 2.14 & Replication, recombination and repair \\
\hline B & 0 & 0.00 & Chromatin structure and dynamics \\
\hline D & 40 & 0.55 & Cell cycle control, mitosis and meiosis \\
\hline V & 127 & 1.75 & Defense mechanisms \\
\hline $\mathrm{T}$ & 210 & 2.91 & Signal transduction mechanisms \\
\hline M & 192 & 2.65 & Cell wall/membrane biogenesis \\
\hline N & 0 & 0.00 & Cell motility \\
\hline U & 34 & 0.47 & Intracellular trafficking and secretion \\
\hline $\mathrm{O}$ & 138 & 1.91 & $\begin{array}{l}\text { Posttranslational modification, protein } \\
\text { turnover, chaperones }\end{array}$ \\
\hline C & 271 & 3.74 & Energy production and conversion \\
\hline G & 318 & 4.39 & Carbohydrate transport and metabolism \\
\hline$E$ & 424 & 5.86 & Amino acid transport and metabolism \\
\hline $\mathrm{F}$ & 105 & 1.45 & Nucleotide transport and metabolism \\
\hline $\mathrm{H}$ & 161 & 2.22 & Coenzyme transport and metabolism \\
\hline । & 187 & 2.58 & Lipid transport and metabolism \\
\hline P & 177 & 2.44 & Inorganic ion transport and metabolism \\
\hline Q & 141 & 1.95 & $\begin{array}{l}\text { Secondary metabolites biosynthesis, transport } \\
\text { and catabolism }\end{array}$ \\
\hline $\mathrm{R}$ & 631 & 8.72 & General function prediction only \\
\hline S & 422 & 5.83 & Function unknown \\
\hline- & 2,790 & 38.50 & Not in COGs \\
\hline
\end{tabular}

The total is based on the total number of protein coding genes in the genome 
Table 5 Open reading frames in the lydicamycin biosynthetic gene cluster

\begin{tabular}{|c|c|c|c|c|}
\hline \multirow[t]{2}{*}{ orf (locus tag) } & \multirow{2}{*}{$\begin{array}{l}\text { size } \\
(\mathrm{aa})\end{array}$} & \multirow[t]{2}{*}{ proposed function } & \multicolumn{2}{|l|}{ BLAST search } \\
\hline & & & protein homolog, origin, accession number & $\%^{\mathrm{b}}$ \\
\hline TPA0598_03_00650 & 473 & acyl-CoA ligase & hypothetical protein, Streptomyces sp. FxanaC1, WP_018093236 & $94 / 96$ \\
\hline TPA0598_03_00660 & 929 & LuxR family transcriptional regulator & $\begin{array}{l}\text { LuxR family transcriptional regulator, Streptomyces sp. FxanaC1, } \\
\text { WP_026170289 }\end{array}$ & $91 / 94$ \\
\hline TPA0598_03_00670 & 274 & unknown & hypothetical protein, Saccharomonospora azurea, EHY88948 & $53 / 64$ \\
\hline TPA0598_03_00680 & 632 & two-component system histidine kinase & hypothetical protein, Streptomyces sp. FxanaC1, WP_018093233 & $93 / 95$ \\
\hline TPA0598_03_00690 & 218 & $\begin{array}{l}\text { two-compornent system response } \\
\text { regulator }\end{array}$ & $\begin{array}{l}\text { LuxR family transcriptional regulator, Streptomyces sp. FxanaC1, } \\
\text { WP_018093232 }\end{array}$ & $99 / 99$ \\
\hline TPA0598_03_00700 & 336 & transacylase & ACP S-malonyltransferase, Streptomyces sp. FxanaC1, WP_026170288 & $89 / 93$ \\
\hline TPA0598_03_00710 ${ }^{\mathrm{a}}$ & 123 & unknown & hypothetical protein, Streptomyces sp. FxanaC1, WP_018093229 & $88 / 95$ \\
\hline TPA0598_03_00720 & 64 & unknown & hypothetical protein JCGZ_17256, Jatropha curcas, KDP45649 & $43 / 54$ \\
\hline TPA0598_03_00730 & 80 & unknown & putative protein-disulfide isomerase, Xanthomonas gardneri, EGD16922 & $56 / 63$ \\
\hline TPA0598_03_00740 & 3,598 & PKS & polyketide synthase, Streptomyces rapamycinicus, AGP57755 & $58 / 69$ \\
\hline TPA0598_03_00750 & 7,054 & PKS & Beta-ketoacyl synthase, Streptomyces violaceusniger, AEM87320 & $57 / 68$ \\
\hline TPA0598_03_00760 & 3,548 & PKS & Beta-ketoacyl synthase, Streptomyces violaceusniger, AEM87320 & $56 / 67$ \\
\hline TPA0598_03_00770 & 1,846 & PKS & Beta-ketoacyl synthase, Streptomyces iranensis, CDR09758 & $62 / 73$ \\
\hline TPA0598_03_00780 & 5,648 & PKS & polyketide synthase type I, Streptomyces aizunensis, AAX98191 & $58 / 69$ \\
\hline TPA0598_03_00790 & 3,662 & PKS & hypothetical protein, Streptomyces sp. FxanaC1, WP_018091594 & $94 / 96$ \\
\hline TPA0598_03_00800 & 3,265 & PKS & polyketide synthase, Streptomyces sp. PRh5, EXU66032 & $54 / 66$ \\
\hline TPA0598_03_00810 & 270 & unknown & hypothetical protein, Streptomyces sp. FxanaC1, WP_018091596 & $95 / 96$ \\
\hline TPA0598_03_00820 & 1,031 & NRPS & hypothetical protein, Streptomyces sp. FxanaC1, WP_018091598 & $94 / 96$ \\
\hline TPA0598_03_00830 & 300 & unknown & hypothetical protein, Streptomyces sp. FxanaC1, WP_018091598 & $96 / 98$ \\
\hline TPA0598_03_00840 & 1,923 & PKS & hypothetical protein, Streptomyces sp. FxanaC1, WP_018091599 & $91 / 94$ \\
\hline TPA0598_03_00850 & 429 & cytochrome P450 & cytochrome P450, Streptomyces sp. FxanaC1, WP_026169967 & $92 / 96$ \\
\hline TPA0598_03_00860 & 260 & unknown & membrane protein, Saccharopolyspora rectivirgula, KEI45939 & $45 / 69$ \\
\hline TPA0598_03_00870 & 253 & type-II thioesterase & hypothetical protein, Streptomyces sp. FxanaC1, WP_018091603 & 95/97 \\
\hline TPA0598_03_00880 & 551 & amine oxidase & amine oxidase, Streptomyces sp. FxanaC1, WP_026169968 & 96/98 \\
\hline TPA0598_03_00890 & 344 & transcriptional regulator & hypothetical protein, Streptomyces sp. FxanaC1, WP_018091605 & 96/97 \\
\hline TPA0598_03_00900 & 496 & amidase & hypothetical protein, Streptomyces sp. FxanaC1, WP_018091606 & $94 / 95$ \\
\hline
\end{tabular}

aencoded in complementary strand, ${ }^{{ }}$identity/similarity

genes for an amine oxidase (TPA0598_03_00880), an acylCoA ligase (TPA0598_03_00650), and a transacylase (TPA0598_03_00700) are present in the surrounding region of the PKS cluster but an amidinohydrolase gene responsible for the hydrolysis of the guanidine residue to the primary amine is lacking (Fig. 5a, Table 5). After the 4-guanidinobutyryl starter is loaded onto ACP of TPA0598_03_00840, the polyketide chain is extended by eight PKSs and a glycine is added to the polyketide terminus by an NRPS module (Fig. 5b), followed by the formation of an octalin and a tetramic acid ring (Fig. 5c). It was not possible to assign a gene responsible for the

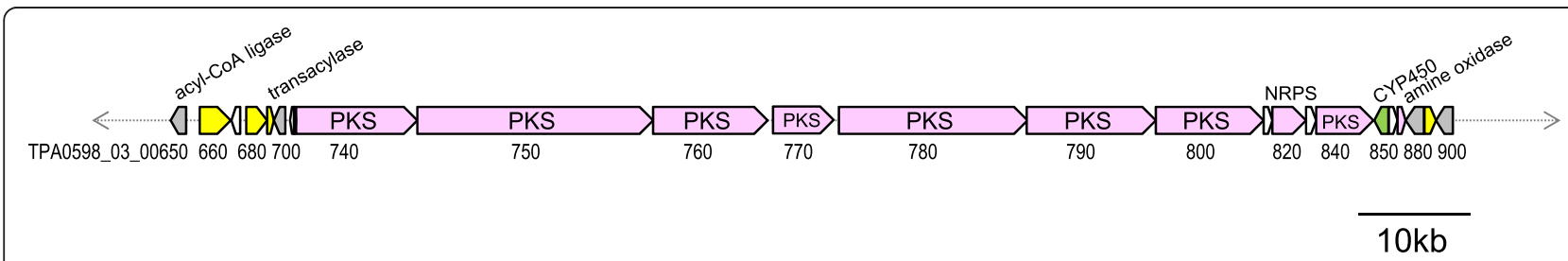

Fig. 4 Genetic map of lydicamycin biosynthetic gene cluster 
a Starter of lydicamycins

transacylase
TPA0598_03_00700 $\begin{gathered}\text { Loaded into loading module } \\ \text { (LM) of TPA0598_03_00840 }\end{gathered}$

Chemical structure of ECO-02301

Starter of ECO-02301

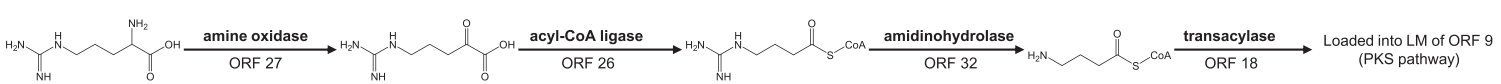

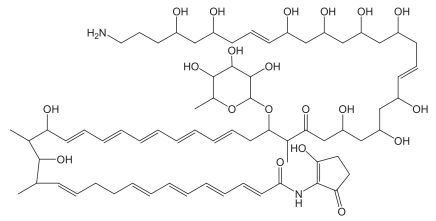

b

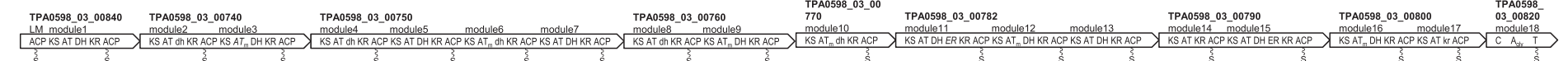
$\sum_{\mathrm{NN}=\mathrm{NH}_{\mathrm{NH}}}^{5} \sum_{\mathrm{NN}}^{\mathrm{S}<}$
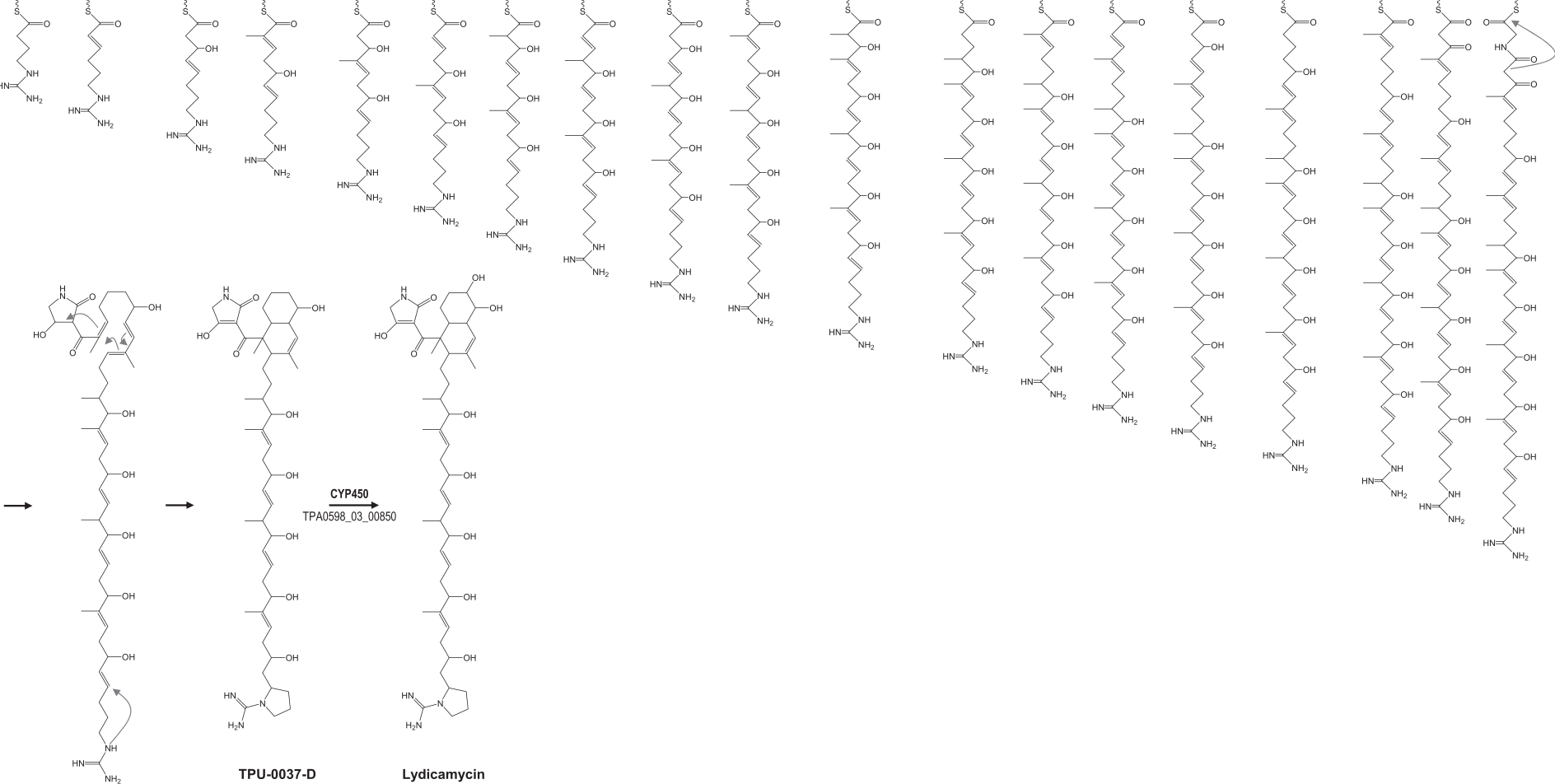

Fig. 5 Proposed lydicamycin synthetic pathway. a starter synthesis compared with that of ECO-02301; b chain elongation; c cyclization and modification yielding final products 
Table 6 Proposed mechanism to produce lydicamycin congeners

\begin{tabular}{llll}
\hline Congener & substrate of m3 $A T_{m}$ & m11 ER & CYP450 \\
\hline lydicamycin & methylmalonyl-CoA & active & involved \\
TPU-0037-A & malonyl-CoA & active & involved \\
TPU-0037-B & methylmalonyl-CoA & inactive & uninvolved \\
TPU-0037-C & malonyl-CoA & active & uninvolved \\
TPU-0037-D & methylmalonyl-CoA & active & uninvolved \\
\hline
\end{tabular}

cyclization of the guanidino precursor into a pyrrolidine ring. A cytochrome P450 (TPA0598_03_00850) would be responsible for the hydroxylation of the octalin carbon at C-8 (Fig. 5c). Production of deoxy- and demethylcongeners suggests that substrate recognition by the AT domain in module3 (second module of TPA0598_03_00740) and the ER domain in module11 (first module of TPA0598_03_00780) is likely not strict (Table 6).

\section{Conclusions}

The $8 \mathrm{Mb}$ draft genome of Streptomyces sp. TP-A0598, a producer of lydicamycins isolated from seawater, has been deposited at GenBank/ENA/DDBJ under accession number BBNO00000000. We successfully identified the PKS/NRPS hybrid cluster for lydicamycin biosynthesis and proposed a plausible biosynthetic pathway. In addition, the genome of strain TP-A0598 contained seven orphan PKS or NRPS gene cluster but secondary metabolites from these orphan clusters have not been isolated yet. The genome sequence information disclosed in this study will be utilized for the investigation of additional new bioactive compounds from this strain and will also serve as a valuable reference for evaluation of the metabolic potential in marine-derived Streptomyces.

\section{Abbreviations \\ $A_{\text {gly: }}$ Adenylation domain whose substrate is glycine; ACP: Acyl carrier protein domain; AT: Acyltransferase domain whose substrate is malonyl-CoA; $A T_{m}$ : AT whose substrate is methylmalonyl-CoA; C: Condensation domain; CoA: Coenzyme A; CYP450: Cytochrome P450; DH: Dehydratase domain; dh: Inactive DH; ER: Enoylreductase domain; ISP: International Streptomyces project; KS: Ketosynthase domain; KR: Ketoreductase domain; kr: Inactive KR; LM: Loading module; m: Module; MRSA: Methicillin-resistant Staphylococcus aureus; NRPS: Nonribosomal peptide synthetase; PKS: Polyketide synthase; T: Thiolation domain; TE: Thioesterase domain.}

\section{Competing interests}

The authors declare that they have no competing interests.

\section{Authors' contributions}

HK identified the lydicamycin-biosynthetic gene cluster and drafted the manuscript. $\mathrm{NI}$ annotated the genome sequence. $\mathrm{AH}$ carried out the genome sequencing. NF organized the genome sequencing. $\mathrm{Yl}$ designed this study and edited the manuscript. All authors read and approved the final manuscript.

\section{Acknowledgements}

This research was supported by a Grant-in-aid for Scientific Research from the Ministry of Education, Culture, Sports, and Technology of Japan to Y.I. We are grateful to Ms. Machi Sasagawa for finding the lydicamycin biosynthetic gene cluster and to Dr. Moriyuki Hamada and Ms. Chiyo Shibata for taking electron micrographs. We also thank Ms. Yuko Kitahashi for finishing genome sequences and annotating PKS and NRPS genes.

\section{Author details}

'Biological Resource Center, National Institute of Technology and Evaluation (NBRC), Chiba, Japan. ${ }^{2}$ NBRC, Tokyo, Japan. ${ }^{3}$ Biotechnology Research Center and Department of Biotechnology, Toyama Prefectural University, Toyama, Japan.

Received: 8 January 2015 Accepted: 21 July 2015

Published online: 26 August 2015

\section{References}

1. Fenical $W$, Jensen PR. Developing a new resource for drug discovery: marine actinomycete bacteria. Nat Chem Biol. 2006;2(12):666-73.

2. Jensen PR, Mincer TJ, Williams PG, Fenical W. Marine actinomycete diversity and natural product discovery. Antonie Van Leeuwenhoek. 2005;87(1):43-8.

3. Lam KS. Discovery of novel metabolites from marine actinomycetes. Curr Opin Microbiol. 2006;9(3):245-51.

4. Furumai T, Eto K, Sasaki T, Higuchi H, Onaka H, Saito N, et al. TPU-0037-A, B, $\mathrm{C}$ and $\mathrm{D}$, novel lydicamycin congeners with anti-MRSA activity from Streptomyces platensis TP-A0598. J Antibiot. 2002;55(10):873-80.

5. Hamada M, Yamamura H, Komukai C, Tamura T, Suzuki K, Hayakawa M. Luteimicrobium album sp. nov., a novel actinobacterium isolated from a lichen collected in Japan, and emended description of the genus Luteimicrobium. J Antibiot. 2012;65(8):427-31.

6. Kim OS, Cho YJ, Lee K, Yoon SH, Kim M, Na H, et al. Introducing EzTaxon-e: a prokaryotic $16 \mathrm{~S}$ rRNA gene sequence database with phylotypes that represent uncultured species. Int J Syst Evol Microbiol. 2012;62(Pt 3):716-21.

7. Kumar Y, Goodfellow M. Reclassification of Streptomyces hygroscopicus strains as Streptomyces aldersoniae sp. nov., Streptomyces angustmyceticus sp. nov., comb. nov., Streptomyces ascomycinicus sp. nov., Streptomyces decoyicus sp. nov., comb. nov., Streptomyces milbemycinicus sp. nov. and Streptomyces wellingtoniae sp. nov. Int J Syst Evol Microbiol. 2010;60(Pt 4):769-75.

8. Thompson JD, Gibson TJ, Plewniak F, Jeanmougin F, Higgins DG. The CLUSTAL_X windows intreface: flexible strategies for multiple sequence alignment aided by quality analysis tools. Nucleic Acids Res. 1997;25(24):4876-4882

9. Perriere G, Gouy M. WWW-query: an on-line retrieval system for biological sequence banks. Biochimie. 1996;78(5):364-9.

10. Field D, Garrity G, Gray T, Morrison N, Selengut J, Sterk P, et al. The minimum information about a genome sequence (MIGS) specification. Nat Biotechnol. 2008;26(5):541-7.

11. Ohtsubo Y, Maruyama F, Mitsui H, Nagata Y, Tsuda M. Complete genome sequence of Acidovorax sp. strain KKS102, a polychlorinated-biphenyl degrader. J Bacteriol. 2012;194(24):6970-1.

12. Hyatt D, Chen GL, Locascio PF, Land ML, Larimer FW, Hauser LJ. Prodigal: prokaryotic gene recognition and translation initiation site identification. BMC Bioinformatics. 2010;11:119.

13. Lowe TM, Eddy SR. tRNAscan-SE: a program for improved detection of transfer RNA genes in genomic sequence. Nucleic Acids Res. 1997;25(5):955-64.

14. Fischbach MA, Walsh CT. Assembly-line enzymology for polyketide and nonribosomal peptide antibiotics: logic, machinery, and mechanisms. Chem Rev. 2006;106(8):3468-96.

15. McAlpine JB, Bachmann BO, Piraee M, Tremblay S, Alarco AM, Zazopoulos E, et al. Microbial genomics as a guide to drug discovery and structural elucidation: ECO-02301, a novel antifungal agent, as an example. J Nat Prod. 2005;68(4):493-6.

16. Woese CR, Kandler O, Wheelis ML. Towards a natural system of organisms: proposal for the domains Archaea, Bacteria, and Eucarya. Proc Natl Acad Sci U S A. 1990;87(12):4576-9.

17. Garrity GM, Holt JG. The road map to the manual. Bergey's Manual of Systematic Bacteriology, Second Edition. Volume 1. New York: Springer; 2001. p. 119-69.

18. Stackebrandt E, Rainey FA, Ward-Rainey NL. Proposal for a new hierarchic classification system, Actinobacteria classis nov. Int J Syst Bacteriol. 1997;47:479-91.

19. Zhi XY, Li WJ, Stackebrandt E. An update of the structure and $16 S$ rRNA gene sequence-based definition of higher ranks of the class Actinobacteria, 
with the proposal of two new suborders and four new families and emended descriptions of the existing higher taxa. Int I Syst Evol Microbiol. 2009;59(Pt 3):589-608.

20. Skerman VBD, McGowan V, Sneath PHA. Approved lists of bacterial names. Med J Aust. 1980;2(1):3-4.

21. Buchanan RE. Studies in the nomenclature and classification of the bacteria: II. The primary subdivisions of the Schizomycetes. J Bacteriol. 1917;2(2):155-64.

22. Kim SB, Lonsdale J, Seong CN, Goodfellow M. Streptacidiphilus gen. nov. acidophilic actinomycetes with wall chemotype I and emendation of the family Streptomycetaceae (Waksman and Henrici (1943)AL) emend. Rainey et al. 1997. Antonie Van Leeuwenhoek. 2003;83(2):107-16.

23. Waksman SA, Henrici AT. The nomenclature and classification of the actinomycetes. J Bacteriol. 1943;46(4):337-41.

24. Wellington EM, Stackebrandt E, Sanders D, Wolstrup J, Jorgensen NO. Taxonomic status of Kitasatosporia, and proposed unification with Streptomyces on the basis of phenotypic and 16S rRNA analysis and emendation of Streptomyces Waksman and Henrici 1943, 339AL. Int J Syst Bacteriol. 1992:42(1):156-60.

25. Witt D, Stackebrandt E. Unification of the genera Streptoverticillium and Streptomyces, and amendation of Streptomyces Waksman and Henrici 1943 339 AL. Syst Appl Microbiol. 1990;13:361-71.

26. Ashburner M, Ball CA, Blake JA, Botstein D, Butler H, Cherry JM, et al. Gene ontology: tool for the unification of biology. The Gene Ontology Consortium. Nat Genet. 2000;25(1):25-9.

27. Saitou N, Nei M. The neighbor-joining method: a new method for reconstructing phylogenetic trees. Mol Biol Evol. 1987;4(4):406-25.

28. Cole JR, Chai B, Farris RJ, Wang Q, Kulam-Syed-Mohideen AS, McGarrell DM et al. The ribosomal database project (RDP-II): introducing myRDP space and quality controlled public data. Nucleic Acids Res. 2007;35(Database issue):D169-72.

29. Zhang Z, Wang Y, Ruan J. A proposal to revive the genus Kitasatospora (Omura, Takahashi, Iwai, and Tanaka 1982). Int J Syst Bacteriol. 1997;47(4):1048-54.

\section{Submit your next manuscript to BioMed Central and take full advantage of:}

- Convenient online submission

- Thorough peer review

- No space constraints or color figure charges

- Immediate publication on acceptance

- Inclusion in PubMed, CAS, Scopus and Google Scholar

- Research which is freely available for redistribution 